\title{
The Symbol of Integration of the Opposite Poles Experienced in the Process of Individuation: Mother
}

\author{
Kim Kyung Nam*
}

\begin{abstract}
$<$ Abstract $>$
The purpose of this study is to examine the mother symbol for a female client in her early thirties by focusing on the dream series and sandplay box referred to in the sandplay therapy course. By focusing on the three themes of nurturing mother, ambivalent mother, and terrible mother, this female client integrates the personal unconscious and the mother archetype energy of the collective conscious in an interesting and sincere journey. As a result, it is possible to see how negative mother archetype transforms into creative and positive energy. Sand play therapy, which provides a safe place for the client's unconscious work, and the mother symbols which appeared in the dream to aid in the healthy self-function of consciousness, helped the client to have appropriate emotional control. It also had a positive effect on improving her physical illness. In addition, this study will examine examples of sandplay of both adults and children, archetypal products and others in order to help understand the three mother symbols. The frequent appearance of the mother figure during the individual process, through the exploration of the inner world, is significant of the many things that need to be resolved within the relationships with one's own mother and even with the archetypal mother.
\end{abstract}

Keywords : mother, symbol, sandplay therapy, dream

* Expert family fact-finding officer of the Cheonan Branch of Daejon District Court and Family Court (knmaria@hanmail.net)

Masters in child welfare, specialty in child counseling and psychotherapy, from Namseoul University 
Journal of Symbols \& Sandplay Therapy, Vol.8 No.2.

\section{I . Introduction}

To all life - humans, animals and plants alike - there is a mother. We come to exist because our mothers have existed before us. Just as everyone has different personalities, looks, hobbies and values, everyone experiences different types of mothers: a tender mother, a friend-like mother, an encouraging mother, an embracing mother, a self-serving mother, an abusive and neglectful mother, an ignorant mother, a strict mother and more. When asked the seemingly simple question to describe their mothers, some may answer easily. But those who pay attention to and explore their inner world may not easily put together an answer. Because a mother is deeply rooted in the individual, from the unconscious realm to the conscious realm, one must first start with self-reflection and then recall and examine various memories related to the mother, such as her personality, virtues, vices, and her reaction to failure and frustration to answer such a question. This process may be compared to the unwilling task of opening up a very dusty box. All recollections regarding the mother and the associations that are made during the process have no relation with the dominant social order. The experience related to a mother is enormous and old, and starts once we are born and lasts throughout childhood (Biedermann, 1989).

Universally, the mother symbol represents the mother of wisdom, the mother of the universe, the mother of all elements and the ruler who controls all spiritual deities. The mother is the origin of all life, has the keys to abundance, and guards the door to birth, death and rebirth. Containing the opposites of creation and destruction, the mother is the creator and nurturer of all life and at the same time the graveyard in which life is buried (Cooper, 1978/1994).

The mother archetype contains opposites: both positive and negative as well as constructive and destructive. The ambivalent mother symbol consists of the goddesses of fate: Nornen, Parzen, Moiren. The negative mother symbol includes the mother-daughter, dragons (or any form of giant fish or snake that swallows and/or coils up everything), graves, stone coffins, the abyss, death, ghosts and monsters that scare children (Jung, 1984/2002).

The mother symbols discussed in this paper will be explained mainly through the 
dreams of a female client in her early thirties. This client at one point realized that she no longer look forward to phone calls with her mother and that she had stopped talking to her mother about little details of her life. She said she felt pity for her mother, but also spiteful at the same time. However, the client could not identify a recent incident that would make her feel this way. She complained that together with her strong feelings towards her mother, she could not control her feelings towards her daughter. She had a vague suspicion that her uncontrollable emotions towards her daughter was somehow connected to her feelings towards her mother. She had a feeling that what was to come had finally come, and wanted to find the connection between the two. Moreover, she had been receiving medical treatment for menstrual irregularity caused by hormonal imbalance for about a year. Medical checkups showed that psychological stress was the biggest reason behind her hormonal imbalance. The therapist felt that the client had reached a point in her life where it was crucial for her to work on her relationship with the mother, which seemed to be an import symbol for her individuation process.

Symbols are signs that fill up the empty space that could not be filled with words; it is a window that shows the emotional and psychic aspects (Tresidder, 2000).

The client began to have dreams related to her mother, as if she has been waiting to do so for a long time. She occasionally experienced feelings of uncontrollable helplessness and depression. She even suffered from extreme body ache for 2-3 weeks. The demands of the unconscious influences one's power of execution and sense of progress, like poison that paralyzes the body (Jung, 1985/2006). An increased consciousness brings about conflict, which was a means to realize new consciousness. As seen in many myths and religious literature, such encounter generally occurs in the wilderness or in a fugitive state, i.e., alienation (helplessness and depression) (Edinger, 1972). The client's unconscious gradually began the work related to the mother through the analysis of her dreams, which will be examined in the following sections.

Although there are many different types of mother symbols, this paper will concentrate on the symbols of the nurturing mother, ambivalent mother and terrible mother that showed up in various sandpictures of different clients. 
Journal of Symbols \& Sandplay Therapy, Vol.8 No.2.

\section{Symbolic meanings of mother}

\section{The Nurturing Mother Symbol}

Humans' speed of development after birth is the slowest of all animals, and hence parental care is indispensable during one's childhood years. The mother especially plays an important role in the child's life, from the time of conception to the child's birth and growth The mother helps fulfill the child's physical and psychological needs. Establishing a stable relationship with the mother is crucial for a child to grow into a healthy adult.

However, not all children develop a stable mother-child relationship. If the mother is psychologically immature, there is a high possibility that the child under her care will undergo an immature development. The primal mother-child relationship determines the quality of all other relationships of the child, which includes not only those with others people, objects, and life events but also that with his or her inner world. (Neumann, 1973; Turner, 2005).

After explaining about her recent feelings towards her mother, the client talked about her past experience:

"I do not remember exactly when, but I remember floundering in water. I do not recall if my mother was there or not. I also remember being scared when I awoke from sleep because my mother was not there. Also, when I was being attacked by a dog, my mother was just focused on doing her laundry at a distance. I was so scared, but she just glanced at me as if nothing had happened. I remember her being happy when my school grades went up. My feelings of loneliness and sadness are bigger than that of pleasure and happiness. It turns out that I was wounded many times, but I had not realize it. But my mother sacrificed so much for me. (Sighs deeply) I feel suffocated, as if someone is suppressing me with something."

Recalling her memories related to her mother, the client was engulfed with sadness and guilt, which she had not been aware of. Guilt is a symptom of disturbed primal relationship. It leads to the conviction that not-to-be-loved is identical with being abnormal and repulsive. This guilt becomes a prevailing feeling in the child (Neumann, 1973). The client, who had received insufficient emotional care during her childhood years, had always strived to become the "good daughter." Believing that she had received devoted and positive nurturing, 
the client worked on her negative feelings toward her mother for a long time. Her negative experiences and feelings were repressed by her personal unconscious, and the repressed energy, or her shadows, was projected as uncontrollable feelings towards her mother and daughter. Recognizing the shadow helped the client to activate deep unconscious. Becoming conscious of the shadow is not just about "seeing" the shadow but to become conscious of both its light and darkness, or, in other words, that the psyche contains wholeness (Lee, 1999). The unconscious continues to send a message to help facilitate the assimilation of the shadow into the consciousness, which can be called the "compensating effect" of the unconscious.

After a few sessions, the client introduced her first dream:

"It was the primitive ages where all animals lived together in herds. Among them, a big elephant and a brown bear were the most memorable. Then the scene changed, and I was being embraced by the elephant. Its skin was very thick and rough, but it felt very cozy. I was very content, as if I were snuggled inside a soft blanket. I found myself closing my eyes, being contained in the elephant."

The client's first dream was the moment of a psychological realization. Generally, the first sandpicture as well as the first dream shows the challenges facing the client, the client's resources and energy, etc. Exploring the shadows led the client to discover in her unconscious her mother's positive care. The elephant and the bear, which are symbols of the mother archetype, delivered the cozy and nurturing aspect of the mother. The elephant's containing function in the dream represents the body vessel, like that of a nurturing mother during the early years of one's life. Clients usually build up their energy before doing deep inner work, and the energy for this client was the positive and maternal experience of the unconscious. Her long journey to confront and solve her mother complex had to start with her childhood nurturing experience.

During the following session, the client created the sandpicture below. While working on her sandpicture, she said she felt warmth, safety, and comfort. In her sandpicture, she expressed the nurturing aspect of the mother archetype through the nature and a rock symbolizing the mother-child unity. The arched door represents the gateway to the unconscious realm: The crystal ball near the center represents the Self, containing the ego germ. The 
Journal of Symbols \& Sandplay Therapy, Vol.8 No.2.

greenery represents the growth of nature as well as Mother Nature. The client, who is represented through the figure sitting on a bench, is looking at the scene in front of her. She seems to represent the independent ego energy, which is merely a germ at the moment, and hence would need to develop in the future. The candle is a symbolism of sacrifice and devotion, as it burns itself to lighten the surroundings, which can be associated with the positive nurturing of a mother. Nurturing energy is also portrayed through the rabbit contained in a bowl-like basket, the positive symbolism of which is to nourish and to protect (Neuman, 1963/1991).

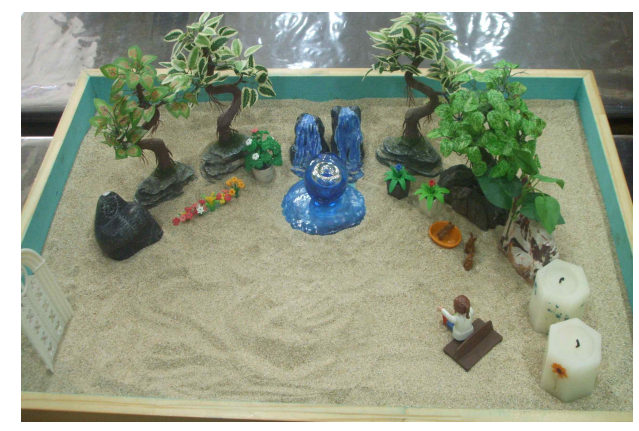

Figure 1-1. A sandpicture created by a female client in her early thirties. It represents the nurturing mother that the client experienced.

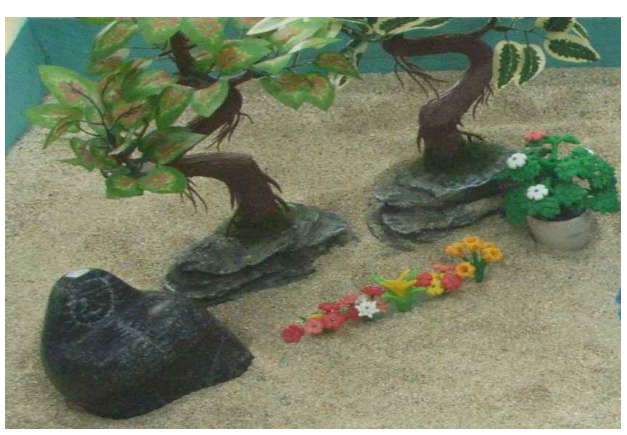

Figure 1-2. A stone figure representing the mother-child unity, and the Mother Nature (close up picture)

During sandplay therapy sessions, the nurturing mother symbol was shown providing food to the figure projected as the client, staying with the figure, and pushing the stroller. The image of feeding signifies the client's need for nurture, or that she is being nurtured through sandplay therapy (Bradway \& McCoard, 1997). When food is consumed, it becomes integrated with the body cell and consequentially transformation occurs. This is the most primal, instinctual experience of transformation for human beings. When food is consumed at a state fatigue, starvation and frailty, we become alert, strong, happy and satisfied. Transformation occurs through not only food but also beverages, as one can regain vitality by satiating thirst. This is what all humans experience for survival, and it is what all humans 
must go through. The act of eating is the primitive form of inner acceptance and conscious realization known to humanity (Neumann, 1954/2010).

A female client in her mid-40s made the following sandpicture, reminiscing about her mother during her childhood. The client was very satisfied with the outcome. With a smile, she explained that she thinks of her mother whenever she feels lonely or helpless in life to regain energy. Her statement indicated that her nurturing mother experience served as a nourishment for her.

The breast motif is a typical symbol of a nurturing mother providing food. Nin-Khursag, a goddess who was the mother for all gods and humans from the Neolithic era to the Bronze Age, provided sacred milk. The breast motif is clearly related to the "nurturing" mother symbol (Neumann, 1963/1991).

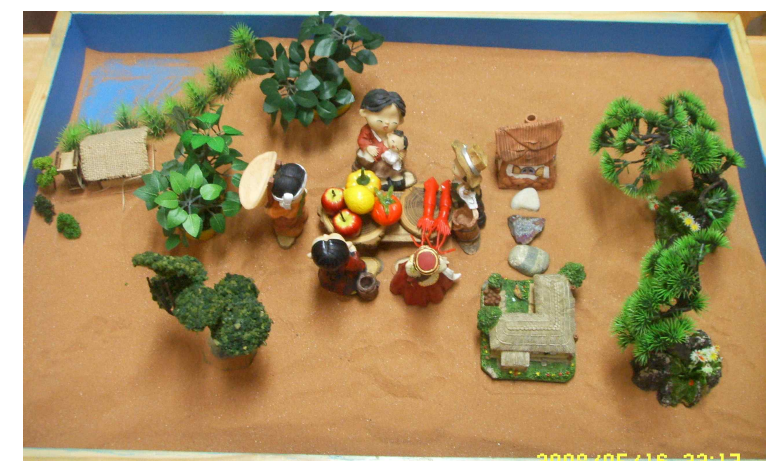

Figure 1-3. Sandpicture of a female client in her mid-40s

A 6-year-old female client who grew up under a helpless and depressed mother sought to gratify her oral needs through sandplay and art. This client placed food figures shaped like a breast in one of her sandpictures. In another session, she created breast-like objects with clay, which she placed in a mandala formation. The pictures implied that she was looking to receive nourishment that she did not receive from her personal mother.

Remarkably, the Mexican goddess Mayauel is portrayed with 400 breasts. The Italian goddess Diana of nature is also a representation of the Great Many-Breasted Mother and a nourisher (Neumann, 1963/1991). 


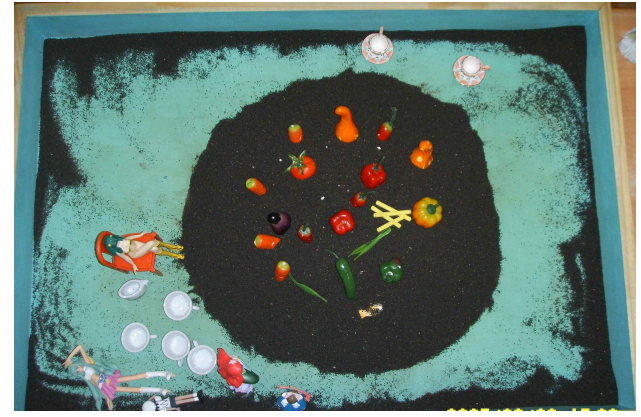

Figure 1-4. A sandpicture created by a 6 -year-old girl to meet her oral needs

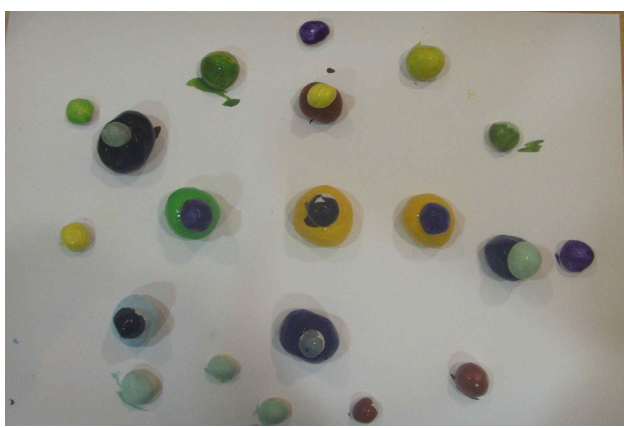

Figure 1-5. Artwork made by a 6-year -old girl

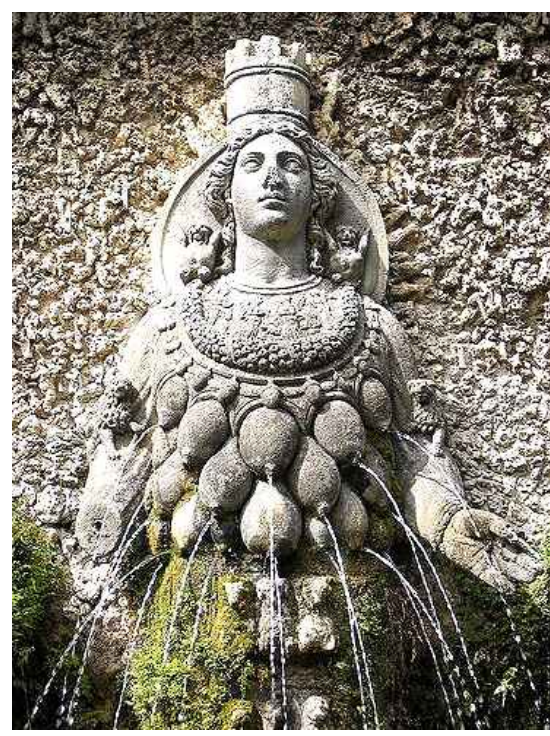

Figure 1-6. Diana at Ephesos

Source: http://www.pholar.co

\section{The ambivalent mother symbol}

One becomes a mother upon giving birth to a child. Even when the mother dies, she stays in her child's psyche, and then in her grandchild's psyche, and so on. According to Jung, as the human race came to being and underwent development, the mother developed into various forms in the human collective unconscious, personal unconscious and the conscious. 
There is "a priori" in every aspect of human activity, a factor which is "inborn, preconscious and unconscious" structure of every individual's psyche. (Jung, 1984/2002). The collective unconscious is not formed by personal experiences; it is the basis of the psyche that exists across humanity. The universal imago that has existed since the ancient times is called the "archetype." Among the archetypes, the Great Mother archetype can be found not only in one's mother, but also in one's grandmother, nanny and housekeeper (Bidermann, 1989).

The nature of the mother archetype may connote anything secret, hidden, dark; the abyss, the world of the dead, anything that devours, seduces, and poisons, that is terrifying and inescapable like fate. (Jung, 1984/2002; Neumann, 1973). The mother archetype contains many opposites: it provides energies of love, hope and support, while also emitting energies of death, engulfing fear and deception.

The middle-aged female client in her 40s, who had ambivalent feelings of pity and dislike towards her mother, introduced her second dream:

"I was fishing at a lake. The water was lukewarm and had a slight viscosity. I had caught two to three small fish but I was afraid that the fish would escape at any moment. The water level suddenly began to rise to the point where it was impossible to get out. I was so scared. Before I knew it, I had become a child floating in the middle of the lake."

Dreaming is a special psychic function that occurs during slumber. This function expresses itself through multiple dreams, rather than one dream. The most fundamental function of the dream is to compensate for the conscious (Lee, 1978). Therefore, understanding the contents of our unconscious through dreams is significant in activating a strong ego, which is at the center of the conscious.

The client's second dream expressed the fear and terror felt by the client's conscious to look at the unconscious. The therapeutic process of overcoming and confronting fear leads into the deep-seated layers of experiences of early childhood (Ammann, 1991).

The fish in the lukewarm lake water represents the awakening of the ego-consciousness, which was not yet able to find and expand its own ground. The ego in its fetal stage can be described as being in the state of "before birth," as it is not in a state where it can have inherent experience; it still remains in the stage of swimming in the fetal 
Journal of Symbols \& Sandplay Therapy, Vol.8 No.2.

ocean, i.e. the womb. Anything big and embracing, like a pond or a lake, which contains, preserves and nourishes anything small belongs to the primordial matriarchal realm (Neumann, 1954). The appearance of a child, who has the potential for a new development, foretells of a new change in the ego. A child is a symbol of something newly born or is yet to be born; it signifies the preconscious. Developing from something that no longer has living energy - old attitudes, developments, and sociocultural paradigms - is called the post-conscious. A child, with its possibility for growth, represents the future in terms of wisdom, hope, aspirations, and potentials (Jang, 2017).

The client soon discovered that she had still wanted to be cared by her mother, when it is actually her who now should be taking care of the elderly mother. She also discovered that her irritation stemmed from her immature attitude toward her mother and realized that she needed to become independent and mature.

Shortly after, the client spoke of her third dream:

"It was the Middle Ages and I went inside a large black cathedral. There was a spiral staircase that led to the deep underground. The staircase bore downwards fathomlessly. Before I knew it, I was heading down the staircase, and as I took the last step I saw a cave. It was dark all around, but a bright light was radiating from within the cave. I didn't know why but it was terrifying. In the cave, a woman was taking care of a young child who was bundled in a white blanket. The moment I recognized the child to be of a very young age, I noticed the woman was looking at me. Her face suddenly turned ghastly, and her skin and teeth were black. I was so terrified that I wanted to run away, but I couldn't move."

The client could vividly recall the woman's hideous face. And while reminiscing about her mother, she recalled that she was afraid of making decisions by herself because she feared of being scolded and corrected by her mother. She associated this with the anxiety she felt when expressing her own opinions. A mother represents refuge, warmth, love and nurture, but excessive nurturance and education can drive a child to reach his or her limits and brings about frustrations. A mother gives life to a child, but she can also endanger and disempower the child (Robert, 1982).

This dream is a surprisingly good illustration of the ambivalent aspect of the mother archetype rooted in the collective unconscious. The structure of a dream is analogous to that of 
Jungian's model of the psyche: going from the external to the internal, deep into the inner world through the spiral steps connected to the underground. The unconscious sends all sorts of vapors, odd beings, terrors and deluding images up into the mind through dreams; for the human kingdom, beneath the floor of the comparatively near little dwelling that we call our consciousness, goes down into unsuspected Aladdin caves. There not only jewels but also dangerous jinn abide: the inconvenient or resisted psychological powers that we have not thought or dared to integrate into our lives. These are dangerous because they threaten the very foundation of order (Campbell, 1949/2008). It is extremely natural that the client had felt fear after facing the ambivalent mother inside the cave, a typical representation of the womb. Jung (1984/2002) once explained there exist a range of representations of the mother archetype, which, in a broad sense, is represented as the underworld or, in a narrow sense, as a cave.

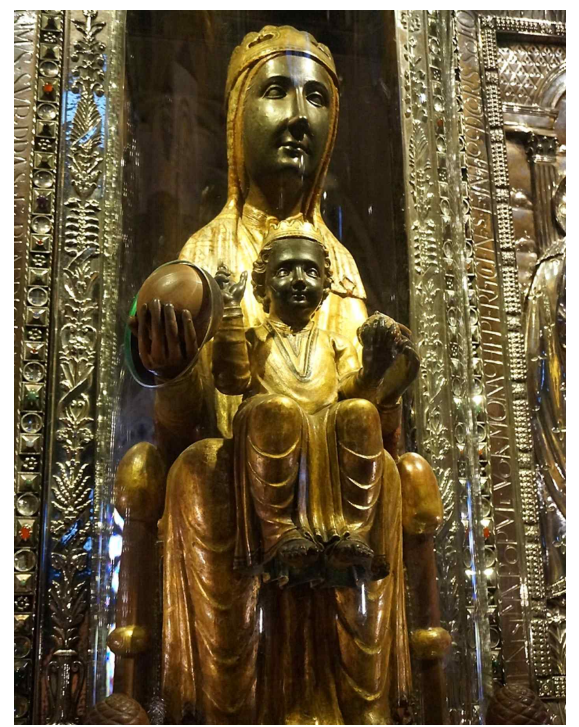

Figure 2-1. The Black Madonna in Barcelona, Spain

Source: http://blog.naver.com/nudement

Marie-Louise von Franz (1999) made references to the "Black Madonna" to illustrate the dark side, or the ambivalent aspect, of the inherently noble, spiritual and pure Virgin Mary. The Black Madonna figure, which found in the Church of Mary built by the early Christians where the Temples of Isis used to stand, represents the dark and frightening aspects 
Journal of Symbols \& Sandplay Therapy, Vol.8 No.2.

of the Virgin Mary. The bright light radiating from within the cave and the child's white blanket are connected to Virgin Mary's positive characteristics, whereas her black skin and hideous face, like those of a witch, demonstrates her negative characteristics, Hence the Black Madonna is a good illustration of an ambivalent mother. It should also be noted that the Black Madonna statue in Barcelona is wearing golden garments.

\section{The Terrible Mother Symbol}

As society has become increasingly industrialized, women have become more educated. Their strengthened desire for self-realization has led to the wish to live a progressive, success-oriented life rather than fulfilling the traditional feminine role of a nurturer. While this is the general direction society has taken in the modern world, it could be interpreted as the reflection of the resentment and the unfulfilled desire of women and mothers, who were traditionally suppressed, disregarded and devaluated, as a group. In a sense, the change in society could be a reflection of the group's desire for compensation through the success of their children.

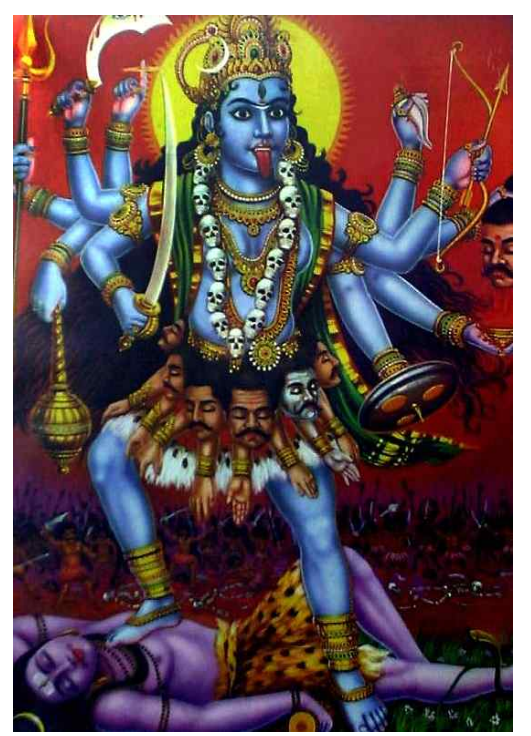

Figure 3-1. Goddess Kali, representing the Terrible Mother

Source: http://egloos.zum.com 
This type of mothers, despite their great motherly sacrifices, cannot commit true sacrifice. Rather, they ruthlessly wield their authority to push their own instincts onto their children, risking both their personality and lives of their children (Jung, 1984/2002).

The client recalled that her mother did not know how to value herself. Her mother had taught her that gaining social recognition is highly important, which, unfortunately, led the client to entrust the nurturing of her daughter to her mother in order to focus on her career. The client's nurturing femininity greatly diminished while her masculinity, which vitalizes one's energy in society, became predominant. This imbalance of psychic energy was expressed through menstrual irregularities. The client's loss of femininity took away the joy and happiness any woman would experience. And the terrible energy, which she was unaware of in the relationship with her mother, was somaticized: Her uterus' resistance towards the mother was manifested as menstrual irregularities, difficulty in conception, and fear of pregnancy. The mother complex brings about a weakening or loss of feminine instincts; the mother complex experienced by the daughter either excessively increases or suppresses her feminine instincts (Jung, 1984/2002).

Images of the terrible mother symbol is usually generated from the "inside." The negative characteristics of femininity are expressed through images that are, in themselves, outlandish and supernatural. In other words, the fearful mother symbolizes the unconscious and hence these images are not formed from the external world. The dark aspects of the mother are often characterized as monsters in countries and cities like Egypt, India, Mexico, Etruria, Bali, or Rome. These witches and vampires, grave spirits that eat the corpses, and goblins all have been macabrely harassing us through myths and fables of all ethnicities, eras, and countries. In India, the experience of the terrible mother has been given its most grandiose form as Kali, "dark, all-devouring time, the bone-wreathed Lady of the place of skulls" (Neumann, 1963/1991).

Soon after, the client introduced her fourth dream:

"I was pregnant and about to give birth. I was sweating a lot and it felt like I was suffocating. I was heading somewhere when I noticed there was nobody around me and I was walking all alone. Strangely enough, I didn't feel lonely or isolated. The scene changed; I was watching myself in labor. There were no doctors around helping me. I gave birth alone and felt 
Journal of Symbols \& Sandplay Therapy, Vol.8 No.2.

relieved and lighthearted."

The client was not biologically pregnant, but rather she embodied the representation of motherhood as a vessel that holds mysteries. The conception of life in the womb could be seen as the rebirth of the dead. The suffocating feeling that had lifted could represent a change in the client's attitude as a woman before birth and after birth. Von Franz (1999) explained birth as a process of transformation on the part of a woman, through which the unconstrained feminine energy becomes dead and undergoes a symbolic proves of rebirth. This change is implied especially because the client's unconscious ego watched over this process, as seen in one of her sandpictures. The unconscious is related to the physical body, and the mother archetype connects the experiences of the unconscious with the physical body (Neumann, 1963/1991). Later the client reported in amazement that she had recovered hormonal balance. The client had transformed the terrible energy of the mother complex into a creative, positive energy. One who is connected to the mother complex is charged to exhibit creativity. In other words, one could break free from the mother complex through creative activities, as the mother complex is not the client's personal mother but something greater, imperceptible and archetypal; something that is connected to the unconscious. Again, only through creative tasks can one escape the mother complex; if not, one will have to face a night of death that seem like a result of heavy drugs, diseases, and aging (Birkhäuser-Oeri, 2003/2012). Dreams are creative pathways to reach the unconscious; in other words, understanding the meaning of dreams can be said to be an act of creativity.

The case of a 12-year-old boy client illustrates how the terrible mother symbol can be manifested in sandpictures. This client suffered from excessive academic stress, which was deeply linked to his mother. The client created the sandpicture below during his first sandplay therapy session, from which the therpiast could detect a destructive mother-son relationship. Spiders represent a terrible, devouring Great Mother energy (Fontana, 1993; Cooper, 1978/1994). The number four, the basis of stability and femininity, evidently shows the client's mother complex that must be overcome. 


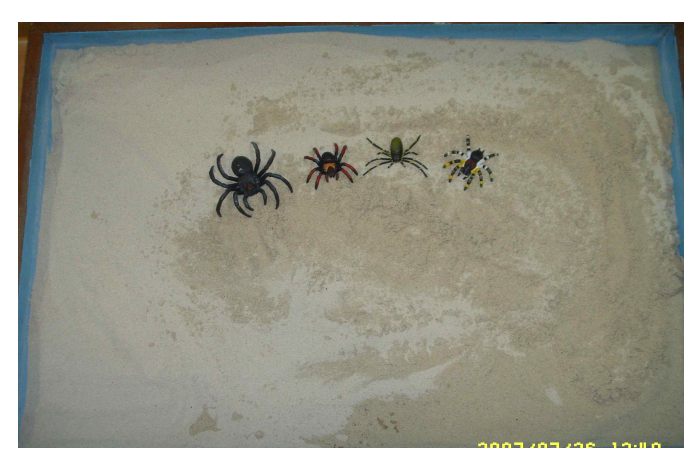

Figure 3-2. Destructive mother archetype sandpicture created by a 12-year-old boy

A 9-year-old boy client, whose chief complaint was poor peer relationships and impulsive aggression, created the following sandpicture halfway past his process. The client's description of his picture is as follows:

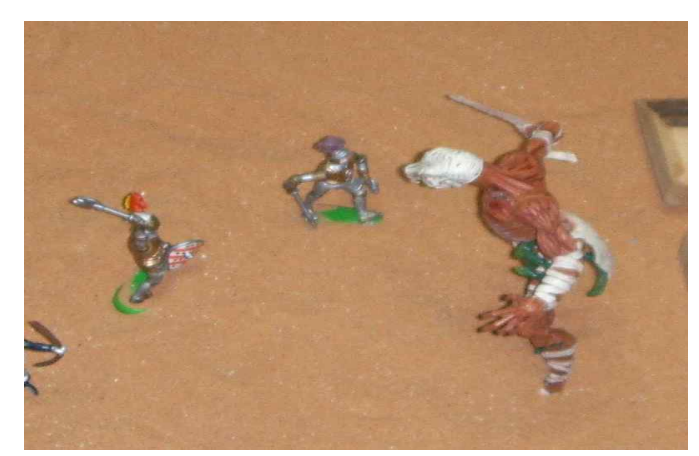

Figure 3-3. Sandpicture in which a 9-year-old boy encountered the mother complex

"[The knights] went on a journey and encountered a monster in an old village. The village will only be peaceful again once the monster is defeated. But there has never been a knight strong enough to defeat the monster yet."

In myths and legends, a hero goes on a journey, usually on a ship, and encounters sea monsters or dragons. The hero tries his best not to be overtaken by the monsters. Similarly, the client also encountered a monster: the terrible mother complex. The story of a 
Journal of Symbols \& Sandplay Therapy, Vol.8 No.2.

knight arriving at the old village is a typical hero motif. The client bravely radiated the potential of his unconscious to overcome obstacles and realized consciousness.

\section{Conclusion}

Sandplay therapists often witness clients' use of mother symbols in sandpictures. The frequent appearance of the mother symbol in the process of individuation signifies that there is much to explore and resolve in one's relationship with the personal mother or the archetypal mother. It is hence highly meaningful to observe the appearance of the mother symbol in clients' dreams and sandpictures. Typically, the function of a dream is to produce materials that bring balance to one's mind, as illustrated by the case of the middle-aged female client who was able to face the various energies of the mother archetype.

The female client faced her emotions and experiences related to her mother that had been suppressed. She therefore recognized her immature attitude of wanting to be cared by her old mother. Through this recognition, she became conscious of her shadows, which facilitated her deeper exploration of the unconscious and became the positive resource to revitalize the energies of the mother archetype. Through her first dream of being in the arms of an elephant, the client experienced the nurturing aspect of the mother archetype. She then received nurturing mother energy through the nature and the mother-child unity symbol in the sandpicture she created soon after. The energy of the nurturing mother triggered her descent into the deeper unconscious. Although the client feared being overwhelmed by the unconscious, she became aware of the need to bring changes to her ego-consciousness, which was still in its prenatal stage, through her second premonitory dream. Through her encounter with a ghastly-faced woman in a cave who bared her teeth while holding a baby wrapped in white cloth, the client became aware of the ambivalent aspect of the mother archetype. After a long conversation with her inner world, the client recognized the opposite aspect of the sacrificial, nurturing, positive mother energy: the terrible mother energy which sought to compensate her unfulfilled social needs through the client. Around that time, the client dreamt of pregnancy and childbirth, which was a signal of the rebirth of the ego that she needed to expand 
consciousness as well as transform the negative mother energy into a creative and positive energy. Through the journey of facing the shadow in her unconscious and becoming conscious of the different energies of the mother archetype, she miraculously experienced healing of her physical illnesses. To the client, the mother symbol was undoubtedly an important symbol that not only helped her to understand of the dynamics of the psyche with a humble attitude and but also connected the conscious and the unconscious for the creation of a new consciousness in her individuation process.

The client encountered the nurturing and positive mother symbol through the breast motif in her sandpicture as well as the four-hundred-breasted goddess Mayauel and the great nurturer goddess Diana. The client also came to understand the ambivalent mother symbol, as explained by von Franz's "Black Madonna" (1999) and the statue of "Black Madonna" in Barcelona, Spain. Also, she came to see that the mother symbol also implied negative mother energy in the abyss, symbolized by as a witch or a vampire in some cultures, and as Kali, the goddess of destruction, in India.

Symbols provide a way for unconscious contents to enter the conscious realm. As symbols themselves are an active expression of such contents, it seems to be the human nature to fearlessly face, accept and feel the different mother symbols that appear in dreams and sandpictures. Respecting this instinct and bravely facing the journey is a part of the individuation process, the process of becoming a mature human being.

I would like to pay my respect to the inner worlds of all adult and child clients that helped me understand the various forms of mother symbols. I would also like to express my gratitude to the clients for inviting me into their unconscious.

\section{References}

Ammann, R. (1991). Healing and transformation in sandplay: Creative processes become visible. Illinois: Open Court.

Biedermann, Hans. (1989). Dictionary of symbol. New York: Penguin Books.

Birkhäuser-Oeri, S. (2003). Die Mutter in Märchen. Fellbach: Bonz. (Trans. into Korean in 2012) 
Journal of Symbols \& Sandplay Therapy, Vol.8 No.2.

Bradway, K., \& McCoard, B. (1997). Sandplay - Silent workshop of the psyche. New York: Buller and Tanner Ltd.

Campbell, J. (1949). The hero with a thousand faced, Novarto, CA: New World Library. (Trans. into Korean in 2008)

Cooper, J. C. (1978). An illustrated encyclopaedia of traditional symbol, New York: Thames and Hudson Ltd. (Trans. into Korean in 1994)

Einder, E. (1972). Ego and archetype. Boston: Shambhala.

Fontana, D. (1993). The secret language of symbols. London: Duncan Barid Publishers Ltd.

Lee, B-Y. (1998). Analytic psychology. Seoul: Ilchokak.

Lee, B-Y. (1999). Shadow. Seoul: Hangilsa.

Neumann, E. (1954). The origins and history of consciousness. Bollingens Series XLII. NJ: Princeton University Press. (Trans. into Korean in 2010)

Neumann, E. (1963). The great mother. Princeton, NJ: Princeton University Press/Bollingen. (Trans. into Korean in 1991)

Neumann, E. (1973). The child. New York: Harper and Row.

Jang, M. (2017). Analytical psychological sandplay therapy. Seoul: Hakjisa.

Jung, C. G. (1984). Archetyp und undewußtes. Dusseldorf: Walter Verlag. (Trans. into Korean in 2002)

Jung, C. G. (1985). Heros und mutterarchetyp. Dusseldorf: Walter Verlag. (Trans. into Korean in 2006)

Robert, S. A. (1982). Dictionary of symbols. Paris: Penguin Books.

Tresidder, J. (2000). Symbols and their meanings. London: DuncanBaird.

Turner, B. A. (2005). The handbook of sandplay therapy. California: Temenos Press.

von Franz, M. L. (1999). The cat: A tale of feminine redemption. Toronto: Inner City Books.

Diana (2015, November 9). Retrieved from http://www.pholar.co/post/359988/7305675

Montserrat (2016, June 23). Retrieved from http://blog.naver.com/nudement?Redirect=Log\&log $\mathrm{No}=220039428964 \&$ from $=$ postView

The Bloody Goddess-Kali (2012, September 25). Retrieved from http://sm20418.egloos.com/ 2894174

Received : October 30, 2017

Revised : December 10, 2017

Accepted : Decebmer 17, 2017 